\title{
Youth Empowerment Based on Participation Through Graphic Design Training
}

\author{
Ade Sadikin Akhyadi*, Wulan Ayu Indriyani \\ Non-formal Education, Faculty of Education \\ Universitas Pendidikan Indonesia \\ West Java, Indonesia \\ *ades.akhyadi@upi.edu,wulanayuindriyani@gmail.com
}

\begin{abstract}
This study investigates youth empowerment using participatory training methods and adult education strategies through graphic design training. The empowerment of young people is a learning approach that adapts to the community's needs. In attempt to optimise youth capacity, it then reacts globally as an action technique in social services. This presents study aims to describe and analyze the participatory methods used for youth empowerment and adult education techniques through graphic design training at PKBM Sukamulya. This research used descriptive method with a qualitative approach. Data was taken by interview, observation and documentation study. To test the validity of the data is done by triangulating data sources. This research took place in Sukamulya City Bandung PKBM. The research subjects consisted of managers, instructors and activity participants. This research found that participatory training methods can encourage youth to identify their individual needs with the training process using adult education techniques. The process of participatory training methods can be taken through several stages, namely the identification of needs, learning contracts, the learning process, evaluation and rediagnosis of community needs.
\end{abstract}

Keywords-youth empowerment, participatory training, adult education

\section{INTRODUCTION}

Poverty is a fundamental problem that occurs in a person, so it must be resolved. Poverty reduction must be done synergistically and systematically so that all people can enjoy a dignified life [1]. The problem of poverty does not only have dimensions on the economic aspect alone, but also on the social, cultural, political, educational, and even ideological levels. In general, poverty conditions are characterized by vulnerability, powerlessness, isolation, and inability to convey their needs and aspirations.

There are several things that cause poverty conditions are still difficult to minimize. First, the condition of community members who have not participated in a quality process, adequate production factors, secondly the low level of education of rural communities, and thirdly the development planned by the government is not in accordance with the community's ability to participate, so it is not reached by the community [2]. Therefore, efforts must be made of new breakthroughs by the government and related parties to immediately help the community raise awareness and the potential it has so that it can benefit the nation's development.

Youth empowerment has grown globally as an intervention strategy in social services to increase youth potential [3]. Youth empowerment assumes that youth agent is formed, in part, through social exchange outside the family that respects or sanctions young people's behavior. As such, youth empowerment programs aim to facilitate social arrangements and interactions between youth and adults that encourage young people to contribute [4]. Youth Empowerment is assessed using two steps, namely the provision of competence and the existence of policy control [5]. In short, empowering the community. Empowerment references to enable individuals to question and challenge structural reasons for their social and economic inequalities, to develop their self-confidence, selfesteem and identity, to shape decisions affecting their lives and to better maintain and promote their livelihoods through learning and action [6]. A friendly and safe environment where young people can identify problems that matter to them [7].

Youth empowerment is an effort to understand its role in making a positive difference in the youth's personality and their present and future lives [8]. Many have suggested that youth access and the use of affordable computer technology will increase inequality, increase learning opportunities. opportunities, and lead to academic and career success [9]. Bishop [10] recognizes the power of young people not as 'children' being controlled and 'children' pacified but as growing adults who have the capacity to be leaders in the present. But in reality there are young people who have limitations and get discrimination and even lose the opportunity to work. Negative factors such as high education costs, recurring unemployment and constant underemployment have caused young people to develop negative attitudes towards life, with low self-esteem and expectations, and feelings of depression, frustration and fatalism [10].

Children and adolescents who live and work on the street or 'street children', as they are commonly known, are socially excluded, marginalized, excluded groups of children and 
adolescents who face various risk factors including discrimination, violence and abuse [11]. They are often faced with lack of access to services but are at high risk of a number of bad outcomes including sexual and reproductive health problems, poor nutrition, substance and alcohol abuse, poor mental health and an increased risk of physical injury [12]. what is meant by vulnerable youths are young people who are easily affected by negative influences from the outside which for one reason or another they cannot continue their education to a higher level of education [13]. As for the vulnerable youth as follows: (1) youth who have dropped out of school, (2) youth in disaster-prone areas, (3) youth who live on the street (street children), (4) youth without families, on average they have lower education which cannot continue to higher education level [14]. Services for 'street children' can take many forms including road outreach programs including skills training, schools and educational programs $[15,16]$.

Seeing the problems and explanations above in Sukamulya Village there is a Community Learning Activity Center namely PKBM Sukamulya. PKBM Sukamulya has implemented several programs in the community based on community empowerment. One of the development activities is graphic design training for youth in Sukamulya Village. This activity has lasted two generations and a third generation will be held. In addition, PKBM Sukamulya has facilities that can support graphic design art activities through a community reading garden program that has partnered with the Perpuseru, the Yasasan Coca Cola Foundation, to provide facilities for libraries both in agencies and in the community. As a results the Perpuseru provided three computer units to support Information Technology and Computer (ICT) services. So this computer can be used by PKBM Sukamulya in graphic village design training for young people around.

Youth Empowerment conducted by PKBM Sukamulya in the form of Graphic Design Training is inseparable from the Empowerment Methods and Techniques. The method used by the PKBM Sukamulya manager is Participatory Training by involving youth to identify the need for themselves accompanied by the PKBM Sukamulya manager, the technique used is also based on adult education because basically youths are included in early adulthood until late adulthood which is rich in rich experience. Based on the problem above, this study will describe the two research questions as follows. 1) Describe the participatory method used for youth empowerment through graphic design training at PKBM Sukamulya 1) Describe adult education techniques used for youth empowerment through graphic design training at PKBM Sukamulya.

\section{METHODS}

This research used a qualitative approach with descriptive method. The purpose of the research is to obtain information and describe the empirical reality behind the phenomenon in depth, in detail and thoroughly. Therefore, the use of a qualitative approach in this study is to match empirical reality with the prevailing theory by using descriptive methods. This study used three participants, namely manager, instructor/tutor and activity participants. This research was conducted at PKBM Sukamulya using interview, observation and documentation study techniques. This study used source triangulation as a data validation technique. It is used for checking and comparing data using the same technique in several different sources.

\section{FINDINGS AND DISCUSSION}

The results of the research conducted by researchers revealed that youth empowerment through graphic design training was motivated by the needs of adolescents and increasingly sophisticated technology. Managers identify according to community needs. Identification is carried out by the manager, tutor, or instructor as well as the youth himself. The purpose of this activity is to fulfill needs and life skills.

The techniques used in the graphic design training process are using adult education techniques and participatory methods. In this case, the manager applies the technique of the adult approach by preparing students, preparing a learning climate for adults, in this case, youth, planning adult learning, diagnosing needs or identifying problems, setting goals, designing learning plans, learning activities, evaluation and things needed after the evaluation there is a need re-diagnosis. Andragogy is a learning process that involv es adult learners in a structure of learning experiences. Andragogy is a big theory of adult learning, methods, techniques, and a set of assumptions about adults [17]. According to Knowles [18], there are fundamental differences regarding the assumptions used by andragogy and pedagogy. Andragogy basically uses assumptions of self-concept, practice, learning readiness, and learning orientation.

In accordance with the sequence in the application of adult education techniques, namely the first stage to prepare students. In this case, there are several components set by the manager and tutor/ instructor in preparing students, namely providing information or understanding to adults (teenagers) about graphic design training, preparing adults (teenagers) to participate in activities by providing socialization and approaches. persuasive, helping adults (adolescents) in developing or providing skills to prepare for the challenges in life, then preparing learning materials for adults (adolescents).

The above is in accordance with Sudjana [19] who argues, the raw input is students or learning citizens with all their characteristics. The results obtained by researchers in research on youth empowerment through graphic design training are the targets of youth empowerment training through graphic design activities are adolescents in Sukamulya Village. The number of participants who took part was $10-20$ people. The number of participants followed by the majority of men. The average age of participants who took part was the productive age. The condition of the participants who took part in the activity was very enthusiastic, but before the training participants did not have competence in the graphic design field. As stated by Sudjana [20], the function of non-formal education planning is an activity related to a systematic first attempt which describes 
the preparation of a series of actions that will be taken to achieve organizational or institutional goals by considering available sources or provided sources. The sources in question are human resources and non-human resources. Human resources are learning tutors, facilitators, tutors, learning citizens, institutional, and community leaders. Non-human resources are facilities, tools, time, costs, and so on. Input means according to Sudjana [19], are sources and means that can be used for learning activities or processes. This input includes curriculum, educators, education, facilities, tools, costs and program management. The results obtained by researchers in adolescent empowerment research through graphic design training, namely there are instructor activities for three people. The facilities used during the activity are computers and laptops as well as modules and the internet. This activity is carried out free of charge from the participants and the manager has a partnership with several parties. In addition, the curriculum, syllabus, and lesson plans used to come from graphic design learning modules that are modified by the tutor or instructor according to the needs of youth in the graphic design field.

Furthermore, learning contracts are important for community learning or activities. Often the community, especially for reasons of work and personal matters, becomes an obstacle in participating in training activities at the institution, so learning contracts become important. The learning contract with the community can be in the form of rules at the time of training together with institutional administrators, then learning objectives will be obtained until the results. Contract learning function for [18]:

- Solves problems from the various backgrounds, education, experiences, interests, motivations, and abilities that characterize most adult groups by providing a way for individuals (and subgroups) to adapt their own learning plans.

- Solving problems make students have a sense of belonging to the goals to be pursued. It solves the problem of identifying multiple sources so that different students can go to different sources to learn the same thing.

- Solving problems gives each student a visible structure to organize his learning.

- Problem-solving provides a systematic procedure for involving students responsibly in evaluating learning outcomes.

Participatory learning activities as a learning effort that includes students in learning activities. According to Sudjana [21], the participation of students is manifested in three stages of learning activities, namely: learning program planning, learning implementation, and learning assessment. Participation in planning is a form of student involvement in the activity of identifying learning needs, problems and determining priority problems, available resources or potential. The results of identification are used as the basis for determining learning objectives and determining learning activity programs. Given that adults have different selfassumptions from students in general, the learning process that must be carried out in training activities, there are several things that are taken in the implementation of the learning process during the adult education process, including Creating a conducive learning climate, diagnosing learning needs, the planning process involves students in preparing training plans, formulating objectives, developing general models, establishing learning materials and techniques [22]

The process of empowering youth through graphic design training is carried out according to the previous plan. The planning includes a graphic design curriculum or module, the facilities used in graphic design activities. Then in its implementation, the time will be determined, the place for graphic design and material activities will be determined at that time. This activity took place at PKBM Sukamulya. The activity time is determined on Saturday and Sunday and there are 12 meetings held. The activity lasts for three months, but the activity does not include the impact that will be felt by the activity participants. Participants will feel the impact of youth empowerment after following the process and continue their training to become young entrepreneurs.

According to Kamil [23], the success of a community empowerment process through non-formal education needs to be done through the following steps: Every citizen learns to be trained to have a high level of sensitivity to social, economic and political developments that occur, citizens learn to be trained or given a variety of skills in response to the needs and problems they face, learning citizens are nurtured to always like to work together in solving a problem.

Researchers rediscovered the process of implementing youth empowerment through graphic design art activities. This is evidenced by the tutor or instructor who applies the group assignment method. Apart from limited facilities, the tutor or instructor divides assignments into groups for participants to complete the assigned tasks. Activity participants must share and work alternately with other activity participants, this can develop collaboration in groups to solve problems. The problem is being able to create innovative and creative graphic design work that is useful for everyday life, such as making banners, banners, logos, book volumes and so on

Community-assisted learning activities can be done face-toface, independently or in tutorials but still based on adult education. for the evaluation of activities which are divided into 4 parts, namely evaluation of reactions, evaluation of learning, evaluation of behavior and evaluation of results.

- Reaction evaluation: This data can be obtained through the final reaction in the form of meetings, interviews, or group discussions.

- Learning evaluation: This step should include a pretest and posttest, so that the specific benefits resulting from the learning experience can be measured. 
- Behavioral evaluation: Sources of data of this type include productivity or time and motion studies; observation scale; self-rating scale; diary; interview schedule; a list of questions; etc.

- Evaluation of results: data usually contained in the organization's routine records - including effects on turnover, cost, efficiency, frequency of accidents or complaints, frequency of delays or absences, denial of quality control, and the like.

Finally, the need to study re-diagnosis. If every learning experience leads to further learning, as is implied in continuing education, then each evaluation process should include some provisions to help students re-examine the desired competency model and reassess the differences between the model and the newly developed competency level. Thus, the repetition of the diagnostic phase becomes an integral part of the evaluation phase. The evaluation of the results will determine whether the community is eligible to develop themselves by continuing with further training or not. If the results are good then it is continued, if the results are not satisfactory, it is necessary to conduct a re-diagnosis for the community in learning so that it is necessary to do repetition at the stage of the learning process.

\section{CONCLUSION}

Participatory training methods can be used for people who are still in a high level of life dependency, so that it provides encouragement to the community to actively participate in development. The use of adult education techniques can be used as an approach in reaching participating communities because the community can provide experience, exchange experiences and have the motivation to learn. The implementation of the program can be done by the community itself without continuing to depend on agents of change. The process of participatory training methods can be taken through several stages, namely the identification of needs, learning contracts, the learning process, evaluation and rediagnose of community needs.

\section{REFERENCES}

[1] S. Miradj and S. Sumarno, "Pemberdayaan masyarakat miskin, melalui proses pendidikan nonformal, upaya meningkatkan kesejahteraan sosial di Kabupaten Halmahera Barat," JPPM (Jurnal Pendidik. dan Pemberdaya. Masyarakat), vol. 1, no. 1, pp. 101-112, 2014.

[2] A. H. Sumarto, Jurus mabuk membangun ekonomi rakyat. Jakarta: Indeks, 2010

[3] M. H. Morton and P. Montgomery, "Empowerment-based non-formal education for Arab youth: A pilot randomized trial," Child. Youth Serv. Rev., vol. 34, no. 2, pp. 417-425, 2012.
[4] M. Morton and P. Montgomery, "Youth Empowerment Programs for Improving Self-Efficacy and Self-Esteem of Adolescents," Campbell Syst. Rev., vol. 7, no. 1, pp. 1-80, 2011.

[5] S. Zeldin, S. E. Krauss, T. Kim, J. Collura, and H. Abdullah, "Pathways to youth empowerment and community connectedness: A study of youth-adult partnership in Malaysian after-school, co-curricular programs," J. Youth Adolesc., vol. 45, no. 8, pp. 1638-1651, 2016.

[6] I.-H. Cheng, "Case studies of integrated pedagogy in vocational education: A three-tier approach to empowering vulnerable youth in urban Cambodia," Int. J. Educ. Dev., vol. 30, no. 4, pp. 438-446, 2010.

[7] S. Greene, K. J. Burke, and M. K. McKenna, "A review of research connecting digital storytelling, photovoice, and civic engagement," Rev. Educ. Res., vol. 88, no. 6, pp. 844-878, 2018.

[8] S. Shobha and N. Kala, "Value education towards empowerment of Youth-A holistic approach," Procedia-social Behav. Sci., vol. 172, pp. 192-199, 2015.

[9] D. B. Shank and S. R. Cotten, "Does technology empower urban youth? The relationship of technology use to self-efficacy," Comput. Educ., vol. 70, pp. 184-193, 2014.

[10] E. Bishop, Becoming activist: Critical literacy and youth organizing. New York: Peter Lang, 2015.

[11] Thomas de Benitez S., State of the World's Street Children: Research. London: Consortium for Street Children, 2011.

[12] J. Morgan, "Participation, empowerment and capacity building: Exploring young people's perspectives on the services provided to them by a grassroots NGO in sub-Saharan Africa," Child. Youth Serv. Rev., vol. 65, pp. 175-182, 2016.

[13] O. R. Sutopo, "Transisi Pemuda Dalam Masyarakat Risiko: Antara Aspirasi, Hambatan dan Ketidakpastian,” J. Univ. Paramadina, vol. 11, no. 3, pp. 1164-1186, 2014.

[14] D. Suranti, M. Maryaningsih, and D. Mardianti, "Pemberdayaan Pemuda Rentan Melalui Pelatihan Multimedia Dikecamatan Sukaraja Kabupaten Seluma Provinsi Bengkulu," Abdimas Dewantara, vol. 1, no. 2, pp. 19 30, 2018.

[15] P. Dybicz, "Interventions for street children: An analysis of current bes practices," Int. Soc. Work, vol. 48, no. 6, pp. 763-771, 2005.

[16] I. Berckmans, M. L. Velasco, B. P. Tapia, and G. Loots, "A systematic review: A quest for effective interventions for children and adolescents in street situation," Child. Youth Serv. Rev., vol. 34, no. 7, pp. 1259$1272,2012$.

[17] N. Sintiawati and S. R. Fajarwati, "Partisipasi Orang Dewasa dalam Sebuah Pelatihan,” Indones. J. Adult Community Educ., vol. 1, no. 1, pp. 26-30, 2019.

[18] M. S. Knowles, The Adult Learner: a neglected species, third edition. Houston: Gulf Publishing Co, 1984.

[19] D. Sudjana, Pendidikan luar sekolah: wawasan, sejarah perkembangan, falsafah \& teori pendukung, serta asas. Bandung: Falah Production, 2000.

[20] D. Sudjana, "Manajemen Program Pendidikan: Untuk Pendidikan Nonformal dan Pengembangan Sumber Daya Manusia," Bandung Falah Prod., 2004

[21] N. Sudjana, Penilaian Hasil Proses Belajar Mengajar. Bandung: PT Remaja Rosdakarya, 2005

[22] A. G. Lunandi, Pendidikan Orang Dewasa. Jakarta: PT Gramedia, 1986.

[23] M. Kamil, Pendidikan Non Formal, Pengembangan Melalui Pusat Kegiatan Belajar Masyarakat. Bandung: CV. Alvabeta, 2009 